\title{
Molecular Basis of Complement C3 Deficiency in Guinea Pigs
}

Harvey S. Auerbach, Reinhard Burger, * Alister Dodds, ${ }^{\ddagger}$ and Harvey R. Colten

Edward Mallinckrodt Department of Pediatrics, and ${ }^{\ddagger}$ The Department of Genetics, Washington University School of Medicine, St. Louis, Missouri 63110; *The Department of Immunology, Robert Koch Institut, Berlin, Federal Republic of Germany

\begin{abstract}
In experiments to ascertain the biochemical basis of a genetically determined deficiency of the third component of complement (C3) in guinea pigs, we found that C3-deficient liver and peritoneal macrophages contain C3 messenger RNA of normal size ( $\sim 5 \mathrm{~kb})$ and amounts, that this mRNA programs synthesis of pro-C3 in oocytes primed with liver RNA and in primary macrophage cultures. In each instance, heterodimeric native C3 protein was secreted with normal kinetics but the $\mathbf{C} 3$ protein product of the deficient cells failed to undergo autolytic cleavage and was unusually susceptible to proteolysis. These data and a selective failure of $\mathrm{C3}$ in plasma of deficient animals to incorporate $\left[{ }^{14} \mathrm{C}\right]$ methylamine suggested either a mutation in primary structure of the $\mathbf{C} 3$ protein or a selective defect in coor postsynthetic processing affecting the thiolester bridge, a structure important for $\mathbf{C 3}$ function. A mutation in the primary structure of $\mathrm{C} 3$ was ruled out by comparison of direct sequence analysis of $\mathrm{C} 3$ cDNA generated from two $\mathrm{C3}$ deficient and two C3 sufficient guinea pig liver libraries. Three base pair differences, none resulting in derived amino acid sequence differences were identified. Finally, restriction fragment length polymorphisms were identified in the $\mathrm{C} 3$ gene that are independent of the deficiency phenotype. This marker of the $\mathrm{C3}$ gene permits testing of these hypotheses using molecular biological and classical genetic methods. (J. Clin. Invest. 1990. 86:96-106.) Key words: immunodeficiency • complement component $\mathrm{C3}$
\end{abstract}

\section{Introduction}

The importance of the complement $(C)^{1}$ system in host defenses and immunopathology has been fully appreciated in the study of congenital and acquired complement deficiencies. The third component of complement (C3) in particular plays a pivotal role in many facets of the inflammatory response. Alper et al. $(1,2)$ first described homozygous deficiency of $\mathrm{C} 3$ in a child with a history of recurrent infections. The principal

Address reprint requests to Dr. Auerbach, Department of Pediatrics, Washington University School of Medicine, $400 \mathrm{~S}$. Kingshighway Blvd., St. Louis, MO 63110.

Received for publication 16 June 1989 and in revised form 13 March 1990

1. Abbreviations used in this paper: $\mathrm{C}$, complement; $\mathrm{C} 3$, third component of complement; C3D, C3 deficient; DOC, sodium deoxycholate; $\mathrm{PCR}$, polymerase chain reaction.

J. Clin. Invest.

(c) The American Society for Clinical Investigation, Inc.

$0021-9738 / 90 / 07 / 096 / 11 \$ 2.00$

Volume 86, July $1990,96-106$ pathogens affecting this child, as in most C3-deficient individuals (3-6), were encapsulated bacteria, thus helping to establish in vivo the importance of $\mathrm{C} 3$ in opsonization, phagocytosis, and intracellular killing of these organisms. However, subsequent reports of C3-deficient individuals have presented conflicting data on defects in other C3-dependent functions such as immune adherence, development of leukocytosis in response to infection, vasopermeability, and antibody response (1-11). One possible explanation for these conflicting data is that, in C3 deficient individuals, C3 is synthesized and secreted, albeit at markedly reduced rates. Some C3 functions might therefore be retained, especially in extravascular sites. This suggestion is supported by observations that monocytes isolated from individuals with $<0.01 \%$ normal serum levels of C3, produced C3 at a rate $\sim 25 \%$ of normal (12). Thus, although the hepatocyte is the primary source of plasma $\mathrm{C} 3$, studies of $\mathrm{C} 3$ biosynthesis in monocytes, fibroblasts and synovial tissue from patients with rheumatoid arthritis (13) suggested that regulation of $\mathrm{C} 3$ synthesis is independent in hepatocytes and other cells in extrahepatic sites. Ethical considerations and other technical constraints, however, did not permit further exploration of these questions in C3-deficient humans.

An isolated genetically determined deficiency of $\mathrm{C} 3$ in the guinea pig has recently been described (14). These animals were derived from an inbred strain 2 colony. Sera from C3 deficient (C3D) guinea pigs contain $\sim 5 \%$ of normal $\mathrm{C} 3$ as assessed functionally and antigenically, i.e., the $\mathrm{C} 3$ appeared to have approximately normal specific hemolytic activity. Preliminary studies (14) suggested that peritoneal macrophages and hepatocytes from the C3D animals produced normal amounts of $\mathrm{C} 3$ and studies of the clearance of ${ }^{125}$ I-radiolabeled normal guinea pig C3 in C3D guinea pigs demonstrated a normal catabolic rate. It is interesting that $\mathrm{C} 3$-deficient guinea pigs mounted only a minimal primary antibody response to $\phi$ $\times 174$, a $T$ cell-dependent antigen, and failed to undergo isotype switching from IgM to IgG with booster immunizations (15). This inadequate antibody response has also been found in deficiencies of complement components of the classical pathway $(16,17)$; all are believed to be due to deficiency of activated $\mathrm{C} 3$.

The availability of a small animal model deficient in C3 prompted further studies of the molecular basis for $\mathrm{C} 3$ deficiency. In this report we show that cells from C3D animals express $\mathrm{C} 3 \mathrm{mRNA}$ similar in size and amount to that found in normal cells. The C3D mRNA programs synthesis of a C3 protein that fails to undergo autolytic cleavage after heating in SDS, a property associated with the presence of a thiolester bridge in the $\alpha$ chain. In addition, a restriction length polymorphism of the $\mathrm{C} 3$ gene has been identified in C3D and some, but not all, C3-sufficient guinea pig strains, providing a marker for the $\mathrm{C} 3$ gene independent of the deficiency phenotype. 

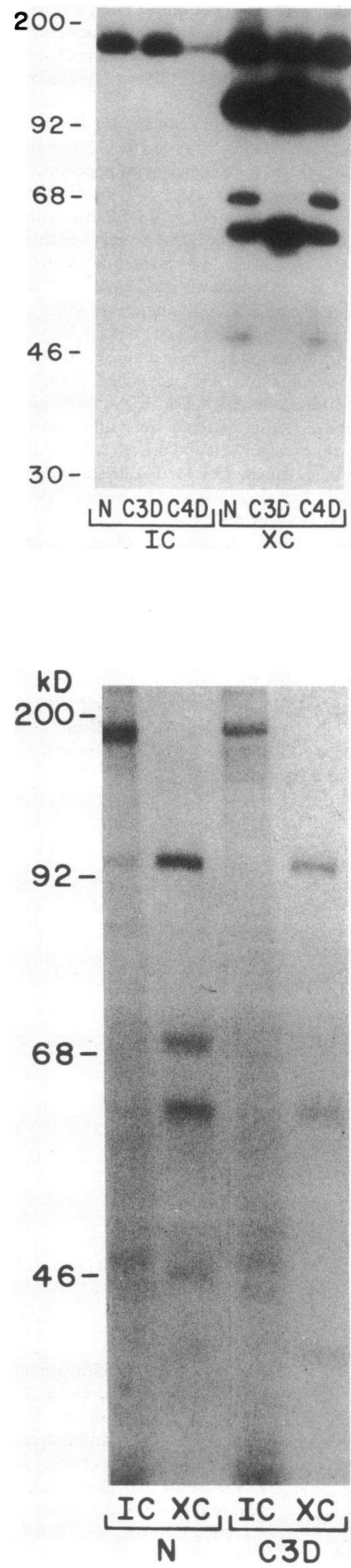

Figure 1. Biosynthesis of $\mathrm{C} 3$ by adherent peritoneal macrophages from normal $(\mathrm{N}), \mathrm{C} 3$ deficient (C3D), and C4 deficient (C4D) guinea pigs. Autoradiograph of reduced SDS-PAGE analysis of intracellular (IC) pro-C3 and extracellular (XC) native $\mathrm{C} 3$ precipitated from culture media.
Figure 2. Biosynthesis of $\mathrm{C} 3$ in Xenopus oocytes primed with liver mRNA from normal (N) or C3D guinea pigs. Pro-C3 (intracellular) and C3 (extracellular) are analyzed by SDSPAGE under reducing conditions.

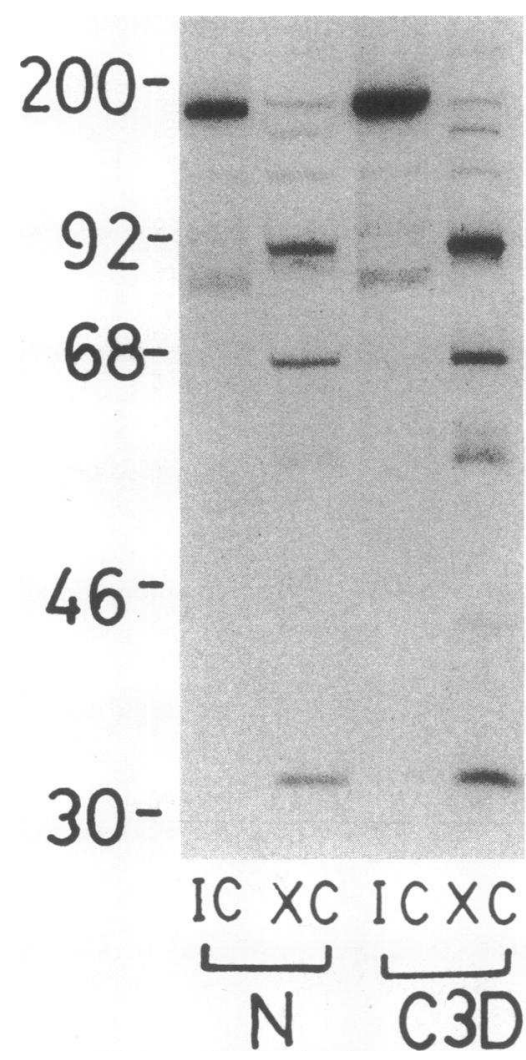

Figure 3. Biosynthesis of $\mathrm{C} 4$ in normal and C3D guinea pig peritoneal macrophages. Analysis of intracellular (IC) pro-C4 and extracellular (XC) native $\mathrm{C4}$ on SDS-PAGE.

\section{Methods}

Cell culture. Peritoneal cells were harvested in HBSS without calcium and magnesium from normal Hartley, C3D, and C4D guinea pigs (C4D guinea pig plasma contains $\mathrm{C} 3$ at normal concentrations). The cells were isolated by centrifugation and resuspended in medium 199 (Gibco Laboratories, Grand Island, NY) with $50 \mathrm{U}$ penicillin and $50 \mu \mathrm{g}$ streptomycin (Gibco Laboratories) per ml supplemented with $10 \%$ heat inactivated $\left(56^{\circ} \mathrm{C}\right.$ for $2 \mathrm{~h}$ ) fetal calf serum (Irvine Scientific Co., Santa Ana, CA) to $4 \times 10^{6} / \mathrm{ml} .0 .5 \mathrm{ml}$ of the cell suspension was placed in 16-mm flat-bottom tissue culture wells (Corning Glass Works, Corning, NY) and the cells were allowed to adhere for $2 \mathrm{~h}$. The monolayers were extensively washed with HBSS (viability was assessed by trypan blue exclusion, differential counts by Wright's stain and stained for esterase) and incubated for specified time periods at $37^{\circ} \mathrm{C}$ in Dulbecco's modified essential medium (DMEM; Gibco) lacking methionine and containing $\left[{ }^{35} \mathrm{~S}\right]$ methionine $(\sim 1,000 \mathrm{Ci} / \mathrm{mmol}$; ICN Biomedicals, Irvine, CA). At timed intervals media were collected, cleared of cell debris by centrifugation at $600 \mathrm{~g}$ for $15 \mathrm{~min}$, then stored at $-70^{\circ} \mathrm{C}$. Macrophage cultures were then washed extensively with HBSS and lysed by freeze-thawing in a solution of $50 \mathrm{mM}$ Tris- $\mathrm{HCl}(\mathrm{pH}=7)$ containing $100 \mathrm{mM} \mathrm{KCl}, 0.5 \%$ Triton X-100 (Sigma Chemical Co., St. Louis, MO) 0.5\% sodium deoxycholate (DOC; Sigma), 2 mM PMSF (Sigma), and 10 mM EDTA.

Immunoprecipitation and analytical gel electrophoresis. Radiolabeled proteins were assayed as previously described (18). Briefly, aliquots of cell lysate or medium were incubated overnight at $4^{\circ} \mathrm{C}$ in $1 \%$ Triton X-100/1\% SDS/0.5\% DOC with excess antibody. A suspension of formalin fixed Staphylococcus aureus bearing protein A (IgSorb; The Enzyme Center, Boston, MA) was then added to each sample and incubated for $1 \mathrm{~h}$ at $4^{\circ} \mathrm{C}$. After extensive washing, the antigen-antibody complex was released by boiling in sample buffer $(0.05$ Tris, $\mathrm{pH}=6.8$, $1 \%$ SDS, $10 \%$ glycerol, 5\% 2-mercaptoethanol, and $0.01 \%$ bromophenol blue), and applied to 9\% SDS-PAGE under reducing conditions. After electrophoresis, gels were stained in Coomassie brilliant 

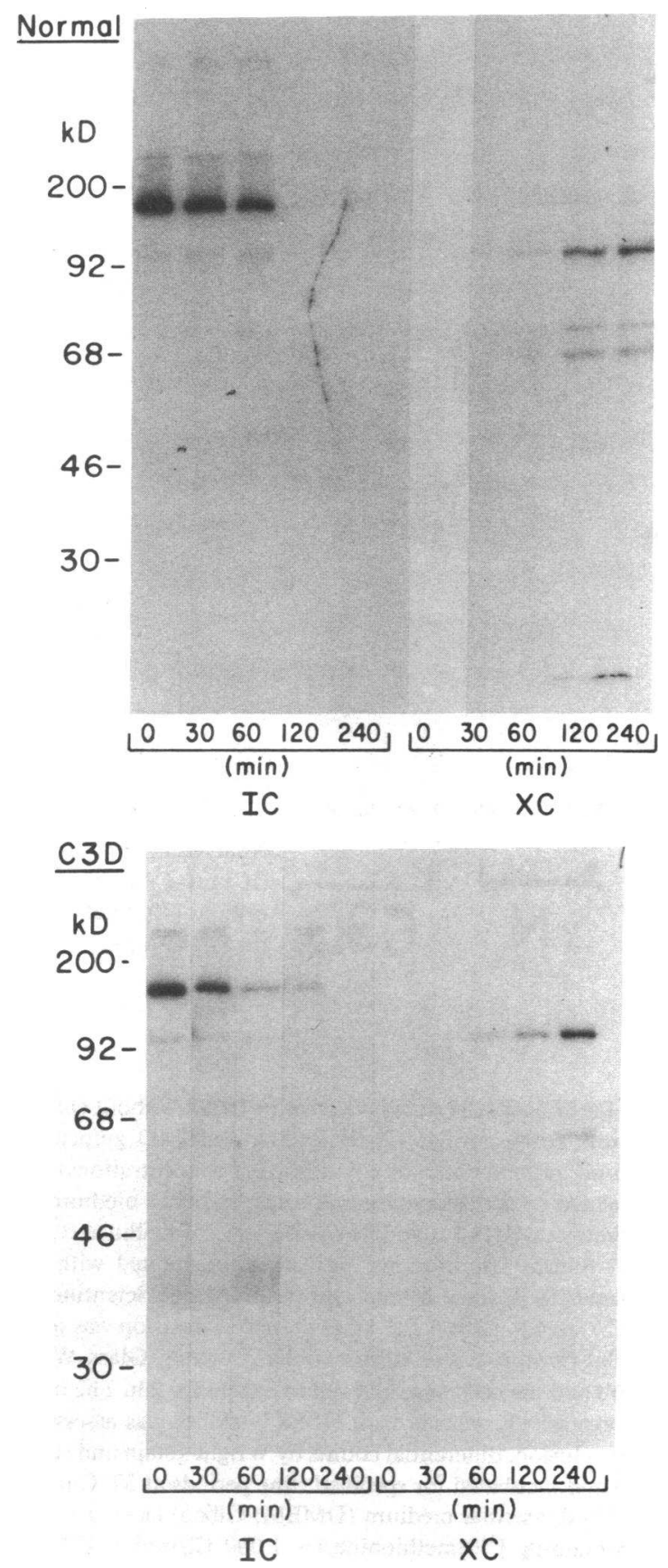

Figure 4. Kinetics of $\mathrm{C} 3$ secretion from normal and C3D macrophages. Cells were incubated with $\left[{ }^{35} \mathrm{~S}\right]$ methionine-containing media for $30 \mathrm{~min}$, then washed and refed with fresh unlabeled media. C3 was immunoprecipitated from intracellular and extracellular samples at indicated time points.

blue, destained, impregnated with 2.5-diphenyloxazole (EN ${ }^{3} \mathrm{HANCE}$; New England Nuclear, Boston, MA), and dried for fluorography on XAR film (Eastman Kodak Co., Rochester, NY).

Antibodies. Antiserum to guinea pig C4 was raised in C4-deficient guinea pigs (19) by previously described methods (18). Antiserum to guinea pig $\mathrm{C} 3$ was raised in albino rabbits by subcutaneous injection of $1.0 \mathrm{ml}$ of a mixture containing equal volumes of purified guinea pig C3, $1.0 \mathrm{mg} / \mathrm{ml}$ (supplied by M. Thomas, Washington University School of Medicine, St. Louis, MO) and complete Freund's adjuvant, followed by two injections at 2-wk intervals of $0.5 \mathrm{mg} \mathrm{C} 3$ in incomplete
Freund's adjuvant. Blood was drawn $5 \mathrm{~d}$ after immunization, and IgG antibody was purified by ammonium sulfate precipitation followed by ion exchange column chromatography (DE52; Pharmacia Fine Chemicals, Piscataway, NJ). Antibody specificity was determined by inhibition of complement lysis and ouchterlony analysis.

C3 proteolysis. Media were harvested from normal Hartley or C3 deficient guinea pig macrophage cultures that had been incubated with $\left[{ }^{35}\right.$ S $]$ methionine for $4 \mathrm{~h}$. Aliquots were incubated with appropriate concentrations of TPCK-treated trypsin (Sigma) for 4-5 min at room temperature. The reaction was stopped by addition of DFP (final concentration $1 \mathrm{M}$ ) at $37^{\circ} \mathrm{C}$ for $20 \mathrm{~min}$. Radiolabeled $\mathrm{C} 3$ protein was then isolated and applied to SDS-PAGE as described above. For autolytic cleavage studies, 50- $\mu$ l aliquots of media from normal Hartley or C3D macrophages previously incubated with $\left[{ }^{35} \mathrm{~S}\right]$ methionine were added to $750 \mu \mathrm{l}$ of $0.1 \mathrm{M}$ Tris acetate, $\mathrm{pH}=8.5$, and $0.1 \%$ SDS. After $20 \mathrm{~min}$ incubation at $75^{\circ} \mathrm{C}, 200 \mu \mathrm{l}$ of a stock solution to yield final concentrations of $1 \%$ Triton X-100, $1.0 \%$ SDS, $0.5 \%$ DOC, was added. Radiolabeled $\mathrm{C} 3$ was then analyzed by immunoprecipitation, SDS-PAGE, and fluorography, as described above. $10 \mu \mathrm{g}$ of RNA were subjected to Northern blot analysis as previously described and probed with ${ }^{32} \mathrm{P}-\mathrm{la}-$ beled mouse $\mathrm{C} 3 \mathrm{cDNA}$ generously donated by $\mathrm{M}$. Takahashi and $\mathrm{M}$. Nonaka (Kanazawa University, Kanazawa, Japan) or with a ${ }^{32} \mathrm{P}-\mathrm{la}-$ beled full length guinea pig $\mathrm{C} 3 \mathrm{cDNA}$ probe.

Xenopus oocytes were injected with $50 \mathrm{ng}$ of mRNA per oocyte. The oocytes were incubated in microtiter wells (Corning Medical Instruments) containing $40 \mu \mathrm{l}$ of Barth's medium/4 oocytes per well at $25^{\circ} \mathrm{C}$ for $6 \mathrm{~h}$ to allow puncture healing and recruitment of mRNA; the oocytes were then refed with DMEM containing $1 \mathrm{mCi} / \mathrm{ml}$ of $\left[{ }^{35} \mathrm{~S}\right]-$ methionine. After $50 \mathrm{~h}$ of incubation at $25^{\circ} \mathrm{C}$, the media were removed. The oocytes were rinsed with PBS and homogenized with a loose fitting Dounce homogenizer (Fisher Scientific, Pittsburgh, PA) in $0.5 \mathrm{ml}$ of $15 \mathrm{mM}$ Tris, $\mathrm{pH}=7.5,50 \mathrm{mM} \mathrm{NaCl}$, and $2 \mathrm{mM}$ PMSF. The homogenates were centrifuged at $100,000 \mathrm{~g}$ for $5 \mathrm{~min}$ and aliquots then immunoprecipitated for $\mathrm{C} 3$, as described above.

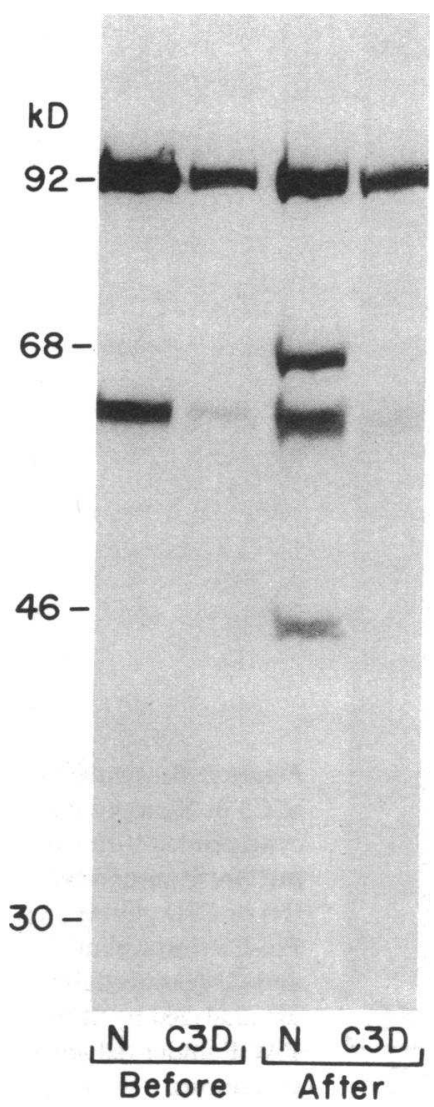

Figure 5. Autolytic cleavage of C3 synthesized in normal and C3D macrophage cultures. SDS-PAGE of C3 immunoprecipitated from extracellular media before and after incubation in $0.1 \%$ SDS, $0.1 \mathrm{M}$ tris acetate, $\mathrm{pH}=8.5$, at $75^{\circ} \mathrm{C}$ for $20 \mathrm{~min}$. 


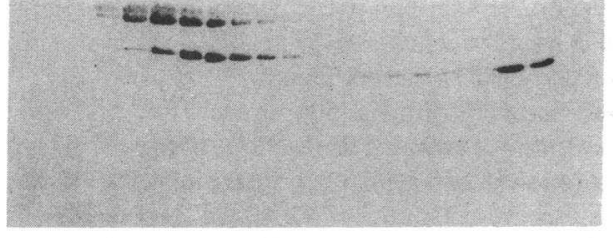

NORMAL

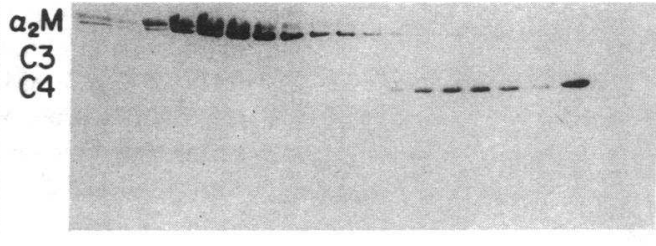

C3 D
Figure 6. Incorporation of $\left[{ }^{14} \mathrm{C}\right]-$ methylamine into guinea pig $\alpha_{2}$ macroglobulin, and the $\alpha$ chain of C3 and C4. Normal and C3D guinea pig sera were fractionated on a $Q$ Sepharose column. Fractions were incubated with $\left[{ }^{14} \mathrm{C}\right]-$ methylamine and analyzed by SDSPAGE and autoradiography. $(A)$ Normal, $(B)$ C3 deficient guinea pig serum. No $\left[{ }^{14} \mathrm{C}\right]$ methylamine was incorporated into the $\mathrm{C} 3$ in the C3D serum fractions (B).
DNA analysis. $1 \mathrm{~g}$ liver fragments from C3D, C4D, C2D, and normal Hartley guinea pigs were digested in $0.5 \%$ SDS, $0.5 \mathrm{M}$ EDTA, $\mathrm{pH}=8$, and $100 \mu \mathrm{g} / \mathrm{ml}$ proteinase $\mathrm{K}$ for at least $6 \mathrm{~h}$ at $50^{\circ} \mathrm{C}$. DNA was extracted from digested solutions by phenol/chloroform, dialyzed against 1,000 times the volume of $10 \mathrm{mM}$ Tris, $\mathrm{pH} 8,1 \mathrm{mM}$ EDTA, and stored at $4^{\circ} \mathrm{C}$. Restriction endonuclease digestion of $10-\mu \mathrm{g}$ aliquots was performed for more than $18 \mathrm{~h}$, and the samples were subjected to agarose gel electrophoresis, transferred to nitrocellulose paper, and hybridized with a ${ }^{32} \mathrm{P}$-labeled full length guinea pig $\mathrm{C} 3 \mathrm{cDNA}$ probe.

Methylamine incorporation in serum C3. A $4 \mathrm{~cm} \times 1 \mathrm{~cm}$ Q Sepharose Fast Flow (Pharmacia Fine Chemicals) column was equilibrated with $10 \mathrm{mM}$ Tris, $5 \mathrm{mM}$ EDTA, $50 \mathrm{mM} \epsilon$-aminocaproic acid, $0.2 \% \mathrm{Na}$ azide, $0.2 \mathrm{mM}$ PMSF, $100 \mathrm{mM} \mathrm{NaCl}, \mathrm{pH} 7.4 .2 \mathrm{ml}$ of normal or C3D guinea pig serum was applied and eluted with a $20-\mathrm{ml}$ gradient to 500 $\mathrm{mM} \mathrm{NaCl}$ in the same buffer. 1-ml fractions were collected. For methylamine incorporation, 22.5- $\mu$ l aliquots of each fraction were incubated with $2.5 \mu \mathrm{l}$ of $2 \mathrm{M}$ Tris, $\mathrm{pH} 8.8$, containing $50 \mathrm{mM}\left[{ }^{14} \mathrm{C}\right]-$ methylamine, $48 \mathrm{mCi} / \mathrm{mmol}$ (New England Nuclear) for $30 \mathrm{~min}$ at $37^{\circ} \mathrm{C}$, then were reduced and subjected to gel electrophoresis on a modified Laemmli gel (20). The gel was stained with Coomassie blue, dried, and exposed to $x$-ray film at $-70^{\circ} \mathrm{C}$

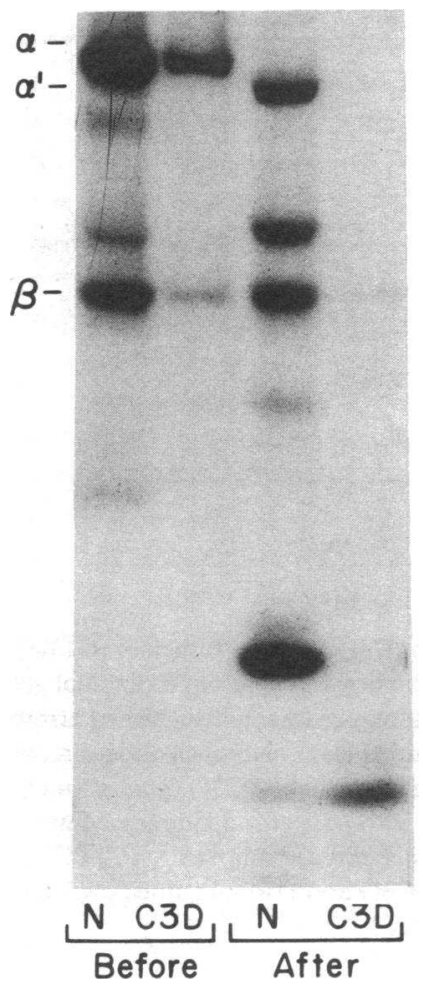

Figure 7. Trypsin cleavage of C3 from normal $(N)$ and $C 3 D$ guinea pig peritoneal macrophages. Native $\mathrm{C} 3$ immunoprecipitated before and after incubation with trypsin. Trypsin cleavage generates an $\alpha^{\prime}$ fragment from normal $\mathrm{C} 3$ but no immunoprecipitable $\mathrm{C} 3$ protein in the C3D sample.
$R N A$. Total liver RNA was isolated from three C3-sufficient (Hartley, one animal, C4-deficient subline of NIH multipurpose guinea pigs, two animals) and two $\mathrm{C} 3$-deficient guinea pig livers according to previously described techniques (21). The polyadenylated RNA fraction was isolated by affinity chromatography on oligo-dT cellulose (22).

Construction of cDNA libraries. The cDNA synthesis system was purchased from Bethesda Research Laboratories (Bethesda, MD); restriction enzymes, $T_{4}$ DNA polymerase, and $T_{4}$ DNA ligase were purchased from New England Biolabs (Boston, MA); dNTPs were purchased from Pharmacia; $S$-adenosyl methionine and Eco RI methylase were purchased from Promega Co. (Madison, WI). Radionuclides $\left[{ }^{32} \mathrm{P}\right] \alpha$-dCTP $(800 \mathrm{Ci} / \mathrm{mmol})$ and $\left[{ }^{35} \mathrm{~S}\right] \alpha$-dATP were purchased from New England Nuclear; oligo-dT cellulose type 3 was purchased from Collaborative Research (Bedford, MA); nitrocellulose HAW filters were purchased from Millipore Corp. (Bedford, MA); phosphorylated Eco RI linkers, lambda ZAP, XL-1 Blue, and Gigapak were purchased from Stratagene (La Jolla, CA); sequenase DNA sequencing kit was purchased from U. S. Biochemicals (Cleveland, OH); SP6/T7 Transcription kit was purchased from Boehringer-Mannheim (Mannheim, West Germany).

The C4- and C3-deficient poly $\mathrm{A}^{+}$was used to direct cDNA synthesis, which was then cloned into lambda ZAP by a modification of the methods described by Okayama and Berg $(23,24)$. Oligo-dT $(12-18)$ or specific oligonucleotides designed from the guinea pig $\mathrm{C} 3$ sequence were utilized as primers for first strand synthesis in generating the primer extension libraries from one additional C3-sufficient (C4 deficient) and C3-deficient animal.

Isolation of $C 3$ cDNA clones. cDNA libraries were plated at a density of $\sim 8,000$ plaque-forming units per 100 -mm dish. Developed plaques were transferred to nitrocellulose filters. Filters were denatured, neutralized, baked in vacuo at $80^{\circ} \mathrm{C}$ for $2 \mathrm{~h}$, prehybridized for 2 $\mathrm{h}$ at $42^{\circ} \mathrm{C}$ in $6 \times \mathrm{SSC}, 1 \times$ Denhardt's solution, $0.5 \%$ SDS, $1 \%$ dextran
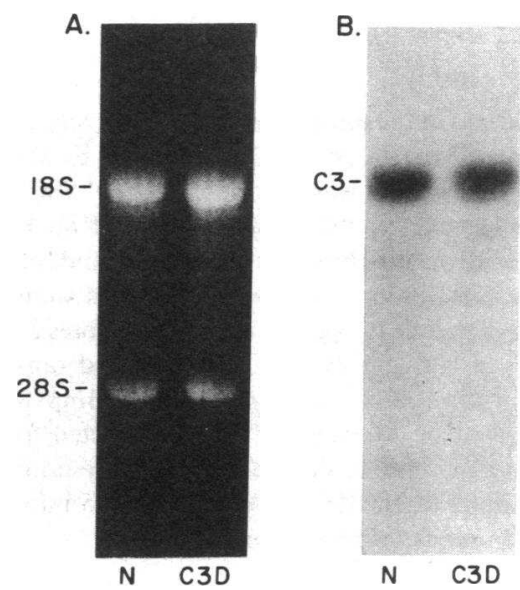

Figure 8. Northern blot analysis of equivalent amounts of RNA isolated from normal and C3D liver visualized under ethidium stain $(A)$ and autoradiography $(B)$. The blot was probed with a full length C3 cDNA. 
A. PST 1

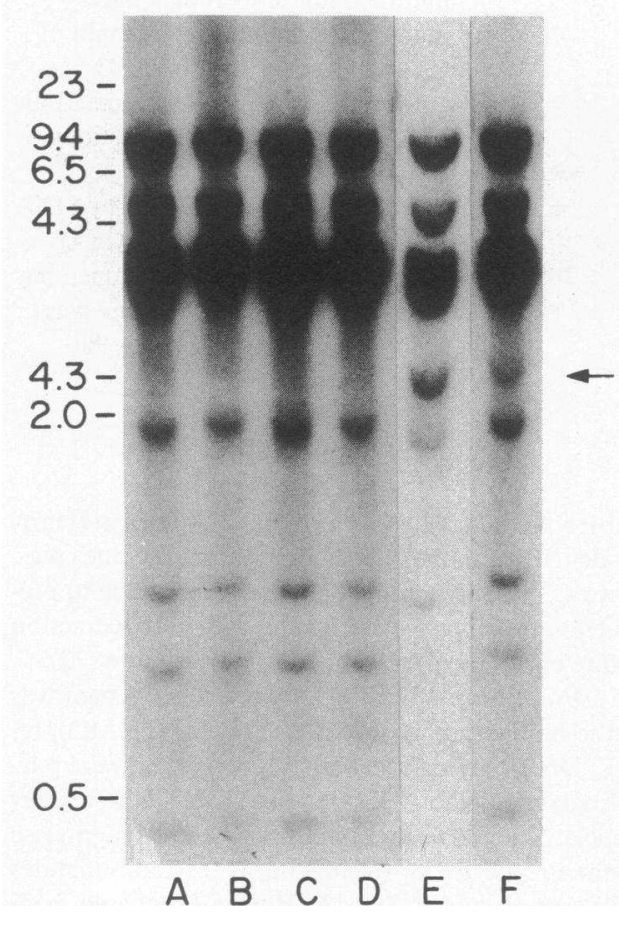

B. ECO RI

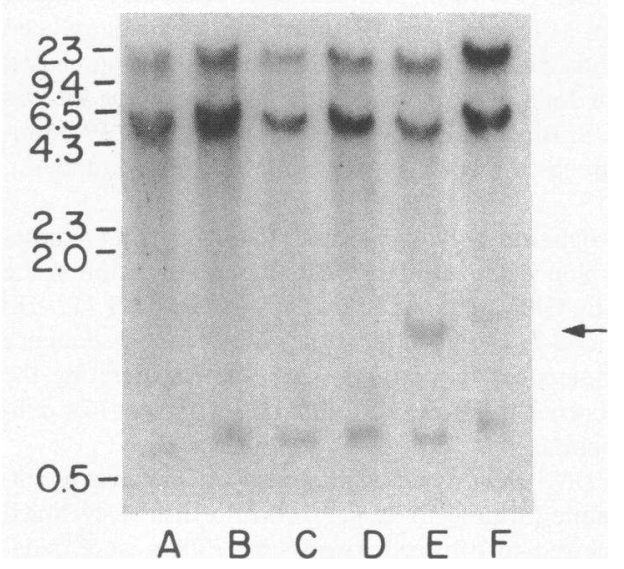

Figure 9. Southern blot analysis of Pst I $(A)$ and Eco RI $(B)$ digests of DNA from $(A)$ normal outbred Hartley, $(B)$ strain $2,(C)$ strain 13, $(D) \mathrm{C}$ 2-deficient, $(E) \mathrm{C} 3$-deficient, and $(F) \mathrm{C} 4$-deficient guinea pigs. Additional $2.3 \mathrm{~kb}$ (Pst 1) and $1.6 \mathrm{~kb}$ (Eco RI) bands are visualized in the $\mathrm{C} 3 \mathrm{D}$ and $\mathrm{C} 4 \mathrm{D}$ lanes.

sulfate, $100 \mu \mathrm{g} / \mathrm{ml}$, and hybridized in the same solution at $42^{\circ} \mathrm{C}$ using a radiolabeled ${ }^{32} \mathrm{P}$-labeled mouse $\mathrm{C} 3 \mathrm{CDNA}$ probe kindly supplied by $\mathrm{M}$. Nonaka and $\mathrm{M}$. Takahashi. Filters were washed at $55^{\circ} \mathrm{C}$ in $1 \times \mathrm{SSC}$, $0.1 \%$ SDS for $1 \mathrm{~h} \times 2$, and subjected to autoradiography using Kodak XAR-5 film. Positive clones were purified by two subsequent rounds of plating and screening. After purification, candidate $\mathrm{C} 3$ clones were digested with Eco RI and subjected to $1 \%$ agarose gel electrophoresis.

$c D N A$ sequencing. $10 \mu \mathrm{g}$ of cDNA was self-ligated, sheared randomly by sonication (six bursts of $40 \mathrm{~s}$ ), subcloned into M13mp 18 according to methods described by Messing (25), and subjected to dideoxy-sequencing. In other experiments, double-stranded bluescript phagemids were denatured in $0.2 \mathrm{M} \mathrm{NaOH}, 1 \mathrm{mM}$ EDTA for $5 \mathrm{~min}$, ethanol precipitated, and then sequenced as above.
Construction of polymerase chain reaction (PCR) fragments. Oligonucleotides (29mers) containing guinea pig $\mathrm{C} 3$ sequences with $5^{\prime}$ restriction endonuclease recognition sites were used to prime first strand cDNA synthesis from C3-deficient and C3-sufficient (Hartley) guinea pig liver mRNA from additional animals of each type. The RNA-DNA hybrid was amplified in a buffer containing $50 \mathrm{mM} \mathrm{KCl}, 35 \mathrm{mM}$ Tris ( $\mathrm{pH}=8.3$ ), $2.5 \mathrm{mM} \mathrm{MgCl}$, bovine serum albumin $(100 \mu \mathrm{g} / \mathrm{ml}), 1.25$ $\mathrm{mN}$ dNTPs, sense and antisense primers ( $500 \mathrm{ng}$ each) and $5 \mathrm{U}$ Taq polymerase in a total volume of $100 \mu \mathrm{l}$. The reactions were carried out for 40 cycles of denaturation $\left(2 \mathrm{~min}\right.$ at $\left.95^{\circ} \mathrm{C}\right)$, primer annealing $(3 \mathrm{~min}$ at $61^{\circ} \mathrm{C}$ ) and primer extension $\left(7 \mathrm{~min}\right.$ at $72^{\circ} \mathrm{C}$ ), in an automated thermal cycler (Perkin Elmer-Cetus, Norwalk, CT). The product was subjected to electrophoresis on a $1 \%$ agarose gel (Seaplaque agarose; FMC Bioproducts, Rockland, ME), and the appropriate sized fragment isolated, phenol extracted and ethanol precipitated. The DNA was digested with the appropriate restriction enzyme, ligated into bluescript phagemid, and sequenced as above.

\section{Results}

C3 biosynthesis. Net biosynthesis of $\mathrm{C} 3$ was assessed in normal Hartley, C3D, and C4D guinea pig peritoneal cell cultures pulsed with $\left[{ }^{35} \mathrm{~S}\right]$ methionine for $4 \mathrm{~h}$. The amount of radiolabeled pro-C3 (intracellular) and native $\mathrm{C} 3$ protein (extracellular) produced was quantitatively similar, and the apparent molecular mass of $\alpha$ chain $(115 \mathrm{kD})$ and $\beta$ chain $(65 \mathrm{kD})$ were indistinguishable in cells from the normal and C3D guinea pigs (Fig. 1). In this experiment, pro-C3 produced by the $\mathrm{C} 4 \mathrm{D}$ cells was apparently present in reduced amounts but the amount of extracellular native $\mathrm{C} 3$ was similar to that produced by the normal and C3D cultures. This decreased amount of pro-C3 in the C4D cells was not a reproducible finding since in four other experiments, the amount of pro-C3 synthesized in C4D cells was similar to that produced in normal and C3D cells. In each culture (normal, C4D, and C3D), the net incor-

A
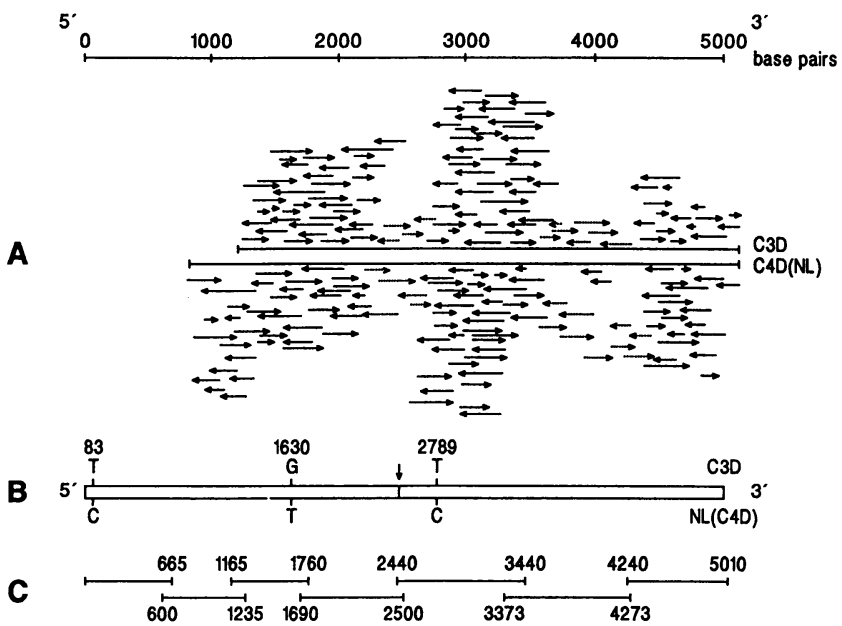

Figure 10. (A) Sequence strategy for C3D- and C3-sufficient (C4-deficient, C4D) C3 cDNA clones. Solid arrows represent individual gel readings from randomly sheared (shotgun) fragments. Dashed arrows represent additional sequence obtained from oligonucleotide-directed sequencing. ( $B$ ) Solid bar represents sequence of $\mathrm{C} 3 \mathrm{D}$ (above) and $\mathrm{C} 3$ sufficient (C4D, below) $\mathrm{C} 3 \mathrm{cDNA}$, with base pair differences identified. Arrow indicates origin of primer extension libraries. $(C)$ PCRgenerated fragments derived from $\mathrm{C} 3 \mathrm{D}$ and normal guinea pig liver mRNA for further sequence analysis. 


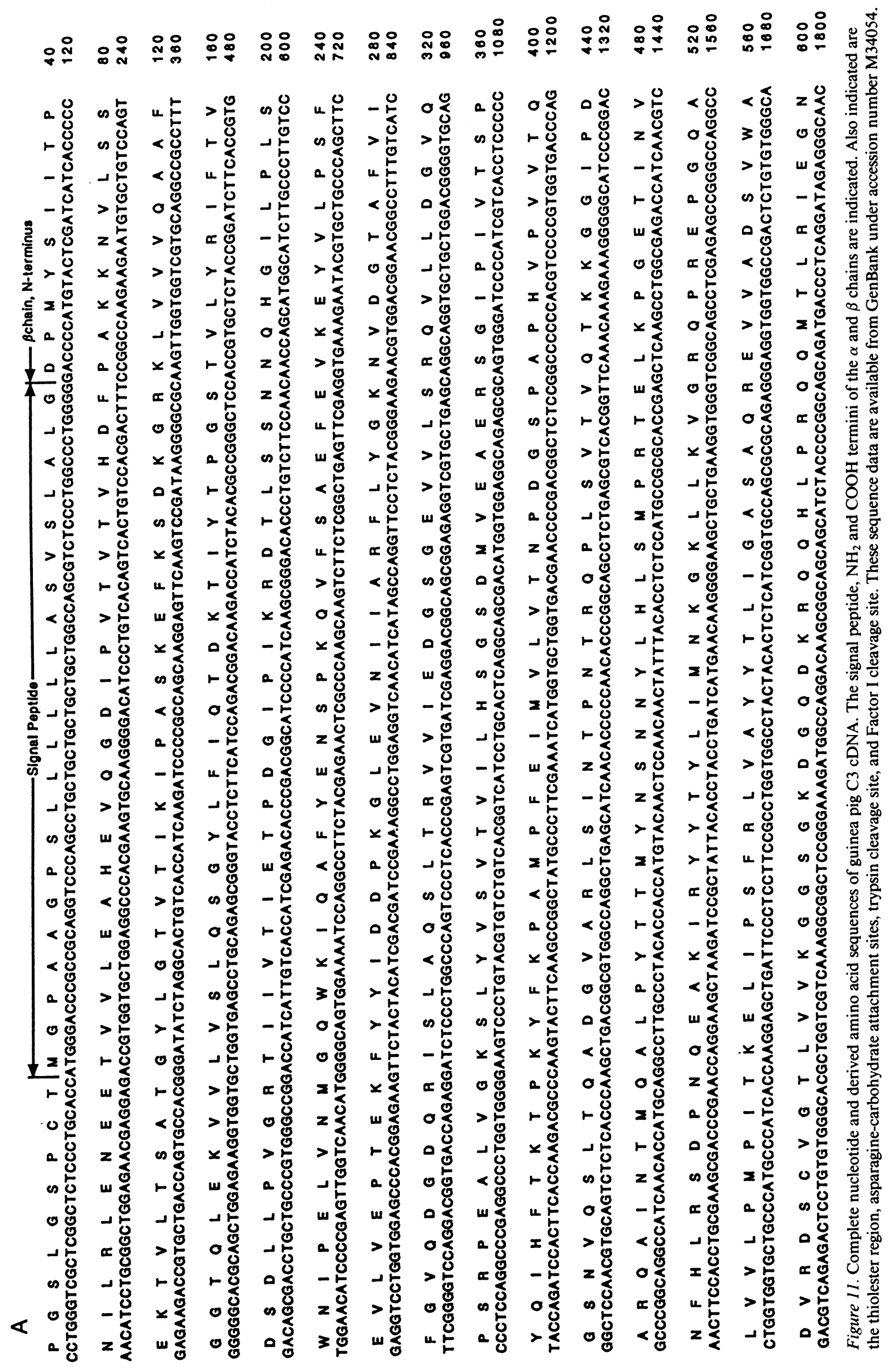




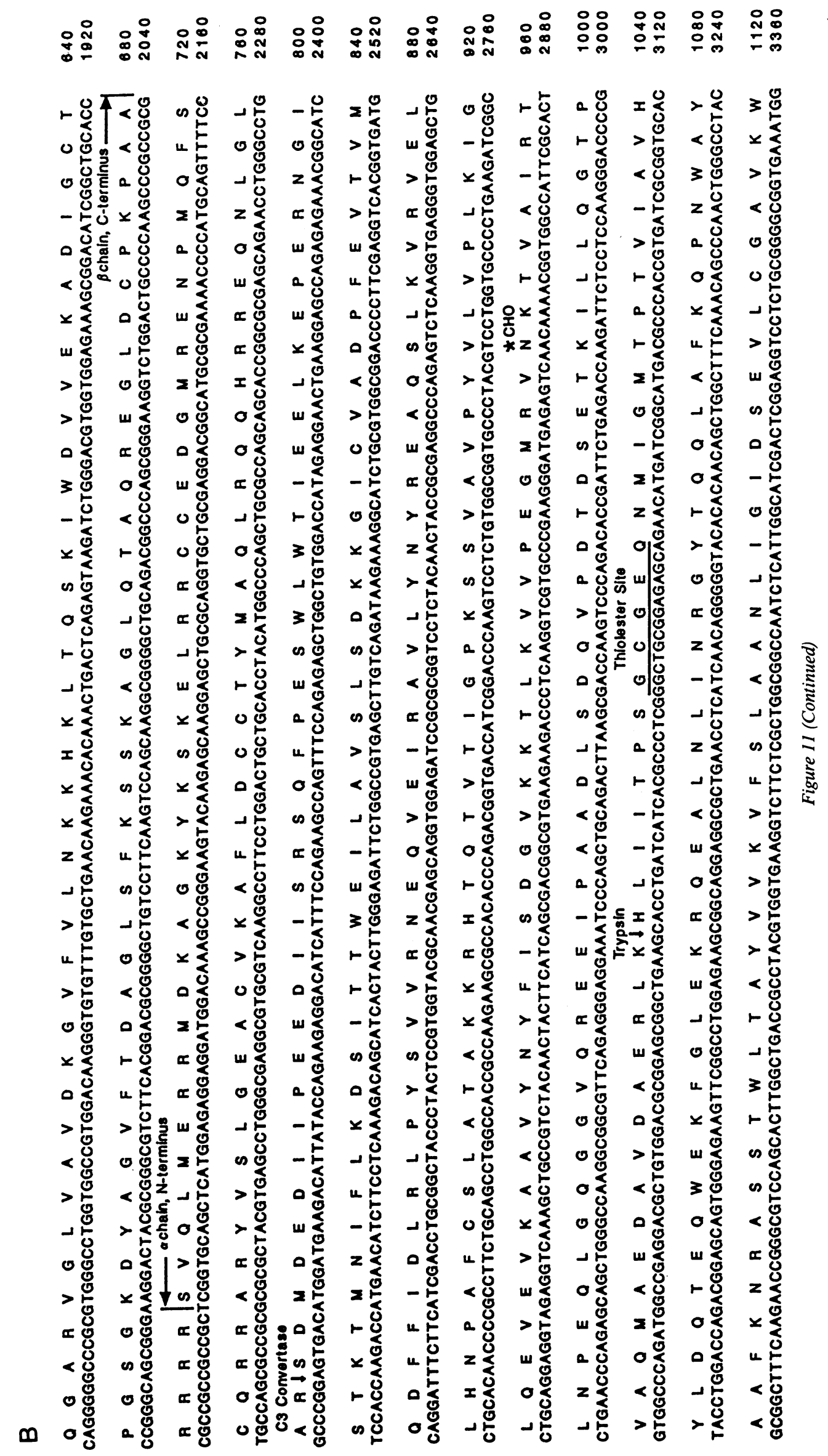


象承

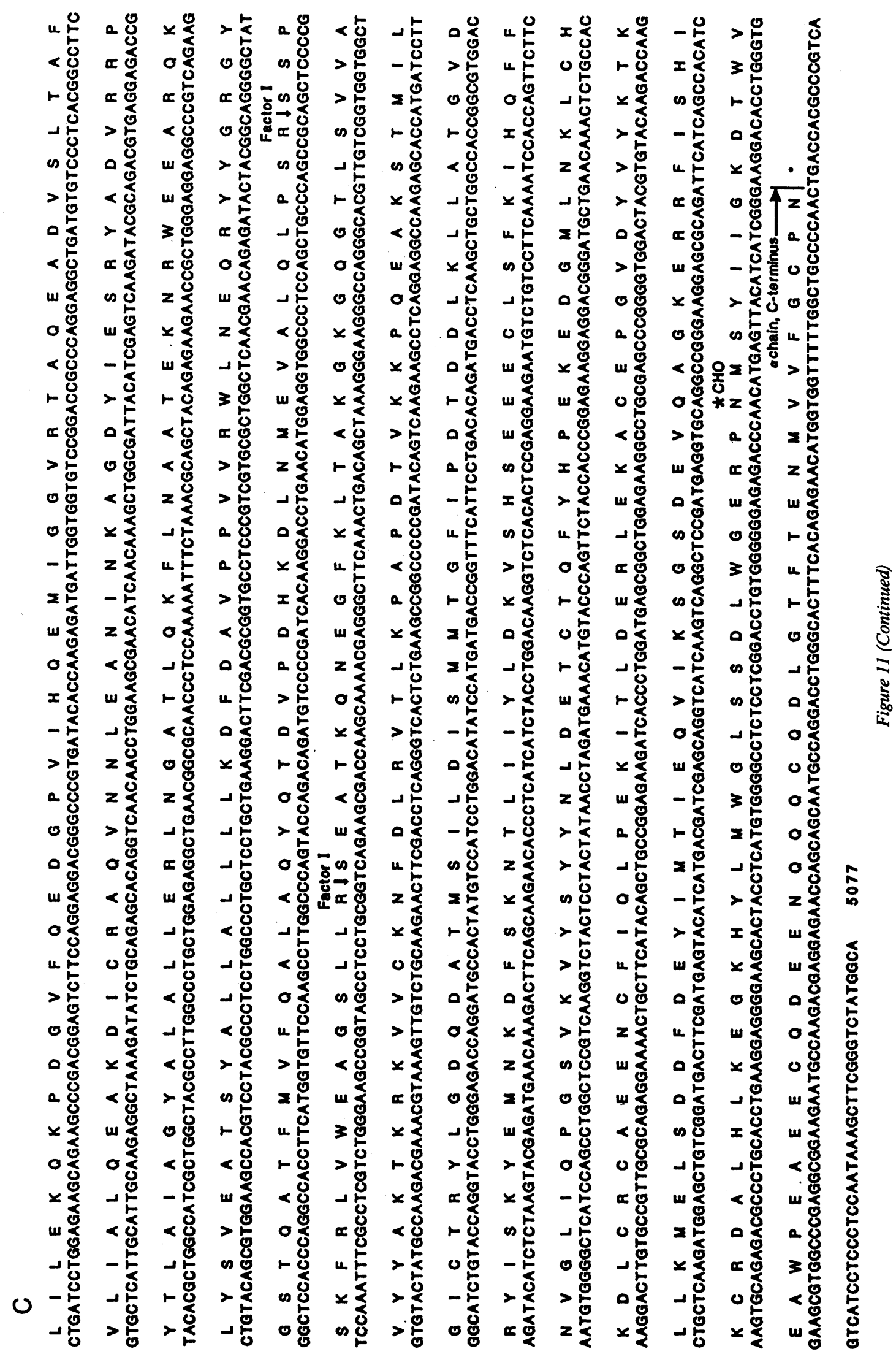


poration of $\left[{ }^{35}\right.$ S $]$ methionine in $\mathrm{C} 3$ of $\alpha$ chain was substantially greater than for $\beta$ chain. Two additional polypeptides $(\sim 70$ $\mathrm{kD}$ and $48 \mathrm{kD}$ ) were detected in the normal and C4D but not the C3D extracellular culture media (see below).

Isolated liver poly $\mathrm{A}^{+}$selected $\mathrm{mRNA}$ from $\mathrm{C} 3 \mathrm{D}$ and normal Hartley guinea pigs generated comparable amounts of pro-C3 and secreted native C3 when injected into Xenopus oocytes pulse labeled for $72 \mathrm{~h}$ with $\left[{ }^{35}\right.$ S]methionine (Fig. 2). The size and subunit composition of the C3D and normal guinea pig liver-derived native $\mathrm{C} 3$ were similar, but again the 70 - and $48-\mathrm{kD}$ products were only visualized when the oocytes were injected with normal mRNA (even overexposed gels failed to demonstrate 70 - and $48-\mathrm{kD}$ products in $\mathrm{C} 3 \mathrm{D}$-injected oocytes [data not shown]). Immunoprecipitation of $\mathrm{C4}$, a complement protein homologous with $\mathrm{C} 3$, from the normal and C3D cultures (Fig. 3) revealed comparable amounts of pro-C4 intracellularly and native $\mathrm{C} 4$ in the extracellular medium.

Secretion of $C 3$. To ascertain the rates of $\mathrm{C} 3$ secretion in normal and C3-deficient cells, peritoneal cell cultures were pulse labeled for $30 \mathrm{~min}$ with $\left[{ }^{35} \mathrm{~S}\right]$ methionine $(500 \mu \mathrm{Ci} / \mathrm{ml})$, washed, and refed with medium containing unlabeled methionine. Cell lysates and media were then assayed for radiolabeled C3 protein (Fig. 4). These data showed that the kinetics of $\mathrm{C} 3$ secretion and net recovery of $\mathrm{C} 3$ protein were similar in the C3D and normal peritoneal cells.

Autolytic cleavage and thiolester bridge. Since the 70 - and 48-kD polypeptides precipitable with antisera to $C 3$ observed in Fig. 1 are similar in size to the previously reported C3 autolytic cleavage products, we attempted to generate these fragments from ${ }^{35} \mathrm{~S}$-labeled native $\mathrm{C} 3$ protein produced in C3D and normal peritoneal cell cultures by incubating the media in dilute alkaline SDS at $75^{\circ} \mathrm{C}$ for $20 \mathrm{~min}(21,26)$. Again (Fig. 5), the 70- and 48-kD bands were visualized only in the normal but not in the C3D-derived culture media.

Methylamine incorporation into plasma C3, C4, and $\alpha_{2}$ macroglobulin. Previous reports have shown that C3D guinea pig plasma contains $\mathrm{C} 3$ both functionally and antigenically at around $5 \%$ of the level found in normals. To examine the possibility that residual $\mathrm{C} 3$ in plasma from C3D guinea pigs differed from that produced in tissue culture the following experiment was performed. Plasma from C3D and normal guinea pigs were fractionated on an ion exchange column and aliquots of each fraction examined for the ability to incorporate ${ }^{14} \mathrm{C}$-labeled methylamine, a function of an intact thiolester bridge. Fig. 6 demonstrates that methylamine was incorporated into $\alpha_{2}$-macroglobulin and C4, two proteins that contain thiolester bonds, in both normal and C3D plasma; methylamine incorporation into $\mathrm{C} 3$ was detected only in normal but not C3D plasma even when the C3D plasma fractions were concentrated $\sim 20$-fold (data not shown) to account for the difference in content of $\mathrm{C} 3$ in the deficient plasma.

Proteolysis. Trypsin cleavage of native C3 protein produced by normal guinea pig peritoneal cells resulted in generation of $\mathrm{C} 3 \mathrm{~b}$, as expected (Fig. 7). However, incubation of the C3D-derived native $\mathrm{C} 3$ protein with between 0.01 and $0.1 \mu \mathrm{g}$ of trypsin (10-fold less than the minimal concentration required for $\mathrm{C} 3 \mathrm{~b}$ generation from normal $\mathrm{C} 3$ ) resulted in complete loss of immunoprecipitable $\mathrm{C} 3$ protein.

C3 transcription. As shown in Fig. 8, Northern blot analysis of total RNA isolated from C3D and C3 sufficient guinea pigs revealed mature $\mathrm{C} 3 \mathrm{mRNA}$ transcripts $(\sim 5 \mathrm{~kb})$ comparable in size and amount. That is, C3 mRNA from normal and C3D guinea pig liver appeared qualitatively and quantitatively indistinguishable. The ethidium-stained gel indicated that comparable amounts of RNA were analyzed.

C3 gene structure. DNA was isolated from Hartley, C2-deficient (strain 13), C4-deficient (strain 13), and C3-deficient (strain 2) animals, digested with several restriction enzymes (Pst I, Eco RI, Bam HI, Hind III, Bgl I, and Sma I) and subjected to Southern blot analysis (27) using a full length normal guinea pig C3 cDNA probe. Fig. 9 shows that digestion with either Pst I or Eco RI resulted in restriction fragment length polymorphisms (additional $2.3 \mathrm{~kb}$ [Pst I] and $1.6 \mathrm{~kb}$ [Eco RI] bands) in the C3D and C4D samples. Since C3 protein synthesis and C3 serum concentrations are normal in C4-deficient guinea pigs, this polymorphism is not a marker for the $\mathrm{C} 3$ deficiency phenotype.

Comparison of C3 cDNA from C3-sufficient and deficient liver libraries. $17 \mathrm{C} 3$ clones from the $\mathrm{C} 3$-deficient library and 25 clones from the C4-deficient library were detected; the largest insert, $3.8 \mathrm{~kb}$ in the C3-deficient and $4.2 \mathrm{~kb}$ in the C4-deficient libraries. Inserts from the three largest clones of each library were isolated and sequenced. As shown in Fig. 10, $\sim 70 \%$ of the cDNA was analyzed using this sequencing strategy, with most regions sequenced several times on both strands. To complete the sequence, oligonucleotides were constructed and used as primers for dideoxy sequencing directly from phagemids. Using this initial strategy, the $C 3$ cDNA sequence extended from the poly(A) tail through the 750 and 1150 most $5^{\prime}$ nucleotides of the $\beta$ chain for C3-deficient and C3-sufficient clones, respectively.

To complete the C3 cDNA sequence, primer extension cDNA libraries were constructed using a C3 specific oligonucleotide (20 mer) corresponding to positions $2469-2488$ of complete guinea pig C3 cDNA sequence. Clones isolated from each library contained sequences that extended 29 nucleotides $5^{\prime}$ of the C3 signal peptide and overlapped by 1312 and 1712 nucleotides, the largest clones from the C3-deficient and C3sufficient libraries. Confirmation of the normal and C3 deficient guinea pig C3 sequence was accomplished by direct sequence analysis of PCR fragments generated from C3 sufficient (Hartley) and C3 deficient mRNA (Fig. 10).

The complete $\mathrm{C} 3$-sufficient (C4 deficient) guinea pig $\mathrm{C} 3$ cDNA sequence and derived amino acid sequence are shown in Fig. 11. The sequence spans 5081 nucleotides, from 29 base pairs upstream of the signal peptide to the beginning of the poly(A) tail. A putative polyadenylation signal, AATAAA, is located 16 nucleotides upstream from the polyadenylation site, and is identical to the polyadenylation signal described for murine $\mathrm{C} 3$ and Slp. The deduced $\mathrm{C} 3$ protein sequence consists of 1666 amino acids in a $\beta-\alpha$ chain orientation with four arginines interposed between the $\beta$ and $\alpha$ chains. The coding region is, therefore, equal in size to murine $\mathrm{C} 3$ and three amino acid residues longer than human C3. Overall, 77-80\% nucleotide and amino acid identity was observed for human, mouse, and guinea pig C3. Complete nucleotide identity between human and guinea pig $\mathrm{C} 3$ sequences was found at the thiolester 15-base pair segment within the flanking 45 base pairs in each direction. Guinea pig C3 shares other structural and functional characteristics with human and murine $\mathrm{C} 3$, including two asparagine carbohydrate attachment sites at positions 
944 and 1620, a trypsin cleavage site between lysine at position 1006 and histidine at 1007 , and two Factor I cleavage sites at positions 1310 and 1327 .

C3-sufficient (C4 deficient) and C3-deficient guinea pig C3 cDNA sequences were compared. Only three nucleotide differences, at positions 83, 1630, and 2789 were found (Fig. 10). These nucleotide differences are "silent" in that they do not result in a difference in the derived amino acid sequences. The sequence of PCR fragments from an additional C3-deficient liver mRNA was identical to the sequence generated from the C3-deficient cDNA and primary extension libraries. The Hartley C3 PCR fragments showed identity with the other C3-sufficient (C4 deficient) C3 cDNA sequence except at positions 83 ( $T$ to $C$ ); i.e., a substitution identical at this position with the C3-deficient sequence.

\section{Discussion}

Several possible explanations were considered to account for discrepancies between serum concentration of $\mathrm{C} 3$ and rate of C3 biosynthesis in previous studies of humans with genetically determined $\mathrm{C} 3$ deficiency $(1-11)$. However, those experiments necessarily monitored $\mathrm{C} 3$ biosynthesis only at an extrahepatic site (blood monocytes) since ethical considerations precluded a direct test of the hypothesis that $\mathrm{C} 3$ synthesis rate in liver was more closely related to the deficiency than C3 synthesis in other tissues. One possibility that was not considered at that time was that a defective $\mathrm{C} 3$ protein susceptible to accelerated catabolism was produced by the deficient cells even though the newly synthesized C3 protein appeared grossly normal by estimates of size and subunit composition. Moreover, a near normal rate of catabolism of normal purified radiolabeled C3 protein was observed in a C3-deficient patient (3). Similar findings were obtained in the initial studies of $\mathrm{C} 3$ catabolism in C3-deficient guinea pigs (14). Preliminary data from those studies also suggested that C3 synthesis is normal in C3-deficient guinea pig hepatocytes.

In the present report we established that liver and peritoneal cells from C3-deficient, normal, and C4-deficient guinea pigs (a) contain C3 specific mRNA indistinguishable in size and quantity by Northern blot analysis, and $(b)$ synthesize pro-C 3 and secrete native $\mathrm{C} 3$ protein at similar rates. Although the $\mathrm{C} 3$ protein produced by the $\mathrm{C} 3 \mathrm{D}$ peritoneal cells or secreted by oocytes primed with C3D liver mRNA appears nor$\mathrm{mal}$ in size and subunit composition it differs from normal $\mathrm{C} 3$ in at least two respects. That is, the C3D-derived C3 protein fails to undergo autolytic cleavage and is unusually susceptible to proteolytic digestion.

C3, C4, and $\alpha_{2}$ macroglobulin are proteins that share an unusual structural feature, a thiolester bridge, important in their respective functions. The phenomenon of autolytic cleavage in dilute alkaline SDS is associated with the presence of an intact thiolester bridge. The $\mathrm{C} 3$ protein produced in C3-deficient guinea pigs, by this criterion, appears to display a defect in the thiolester bridge or its accessibility. Support for this concept and for the selectivity of the defect is provided by demonstrating incorporation of methylamine into C4 and $\alpha_{2}$ macroglobulin, but not into $\mathrm{C} 3$ of $\mathrm{C} 3$ deficient plasma even when the samples are concentrated $\sim 20$-fold to increase the C3 content in the C3D sample to near normal levels. An abnormality in primary or higher order structure of the C3-defi- cient $\mathrm{C} 3$ protein is also suggested by the unusual susceptibility of this protein to proteolysis. The rate of in vivo catabolism of this abnormal C3 protein is unknown because previous estimates of $\mathrm{C} 3$ metabolism in the deficient animals as in studies of C3D humans were obtained using normal purified radiolabeled C3 protein (14).

These data are consistent with (a) a mutation in the coding region of the $\mathrm{C} 3$ gene leading to a defect in primary or higher order structure affecting the thiolester bridge or its accessibility, (b) a C3 specific co- or post-translational processing defect that affects the thiolester bridge; i.e., a genetic defect unlinked to the $\mathrm{C} 3$ gene. The finding of a restriction fragment length polymorphism (RFLP) that does not correlate with the C3 deficiency phenotype lends support to the latter hypothesis. That is, the RFLP provides a marker for the C3 structural gene distinct from the deficiency phenotype. Sequence analysis of C3 cDNA from C3 deficient guinea pig liver libraries ruled out a mutation in primary structure of the $\mathrm{C} 3$ gene as the basis for this genetic defect.

Sequencing of C3 cDNA clones from two separate C3 deficient liver libraries and from PCR fragments generated from a third C3-deficient liver mRNA preparation established that the $\mathrm{C} 3$ coding regions in C3-sufficient and deficient guinea pigs is identical except for positions 83,1630 , and 2789. None of these substitutions result in an amino acid difference. At position 83 the Hartley (C3 sufficient) sequence is identical to the C3-deficient sequence. These data thus support the hypothesis that $\mathrm{C} 3$ deficiency in guinea pig is due to a co- or postsynthetic processing modification that renders the $\mathrm{C} 3$ protein highly susceptible to proteolysis.

The biochemical mechanism by which the thiolester bridge is generated in C3 is uncertain. Kahn and Erickson (28) suggested that isomerization of a lactam ring to generate the thiolactone proceeds spontaneously under physiological conditions, though they could not rule out an enzymatically facilitated process. Iijima et al. (29) on the other hand provided tentative evidence for participation of a cytoplasmic factor (possibly an enzyme) in the formation of the C3 thiolester. Heretofore, investigators have assumed but not tested the assumption that the mechanisms for generation of the C3, C4 and $\alpha_{2}$ macroglobulin thiolesters are identical. Since the mutation accounting for $\mathrm{C} 3$ deficiency is not in the coding region of the $\mathrm{C} 3$ gene, this defect provides a probe to examine co- and postsynthetic processing of this important group of proteins. Molecular biological and classical genetic studies are underway to test this hypothesis.

\section{Acknowledgments}

We thank Barbara Pellerito for excellent secretarial assistance.

This work was supported by National Institutes of Health grants AI-24836 and HL-37591.

\section{References}

1. Alper, C. E., H. R. Colten, F. S. Rosen, A. R. Rabson, G. M. McNab, and J. S. S. Gear. 1972. Homozygous deficiency of C3 in a patient with repeated infections. Lancet. ii:1179-1181.

2. Alper, C. E., H. R. Colten, J. S. S. Gear, A. R. Rabson, and F. S. Rosen. 1976. Homozygous human C3 deficiency. J. Clin. Invest. 57:222-229.

3. Alper, C. E., R. P. Propp, M. R. Klemperer, and F. S. Rosen. 
1969. Inherited deficiency of the third component of complement. $J$. Clin. Invest. 48:553-557.

4. Ballow, M., J. E. Shira, L. Harden, S. Y. Yang, and N. K. Day. 1975. Complete absence of the third component. J. Clin. Invest. 56:703-710.

5. Borzy, M. S., A. Gewurz, L. Wolff, D. Houghten, and E. Lovrein. 1988. Inherited C3 deficiency with recurrent infections and glomerulonephritis. Am. J. Dis. Child. 142:79-83.

6. Hsieh, K. H., C. Y. Lin, and T. C. Lee. 1981. Complete absence of the third component of complement in a patient with repeated infections. Clin. Immunol. Immunopathol. 20:305-312.

7. Davis, A. E., J. S. Davis, A. R. Rabson, S. G. Osofsky, H. R. Colten, F. S. Rosen, and C. A. Alper. 1977. Homozygous C3 deficiency: Detection of $\mathrm{C} 3$ by radioimmunoassay. Clin. Immunol. Immunopathol. 8:543-550.

8. Cochrane, C. G. 1984. The role of complement in experimental disease models. Springer Semin. Immunopathol. 7:263-270.

9. Osofsky, S. G., B. H. Thompson, T. F. Lint, and H. Gewurz. 1977. Hereditary deficiency of the third component of complement in a child with fever, skin rash, and arthralgias: response to transfusion of whole blood. J. Pediatr. 90:180-185.

10. Sano, Y., H. Nishinukai, H. Kitamura, K. Nagaki, S. Inai, Y. Hamasaki, I. Maruyama, and A. Igata. 1981. Hereditary deficiency of the third component of complement in two sisters with systemic lupus erythematosis-like symptoms. Arthritis Rheum. 24:1255-1267.

11. Burger, M., J. E. Balow, C. B. Wilson, and M. M. Frank. 1983. Circulating immune complexes and glomerulonephritis in a patient with congenital absence of the third component of complement. $N$. Engl. J. Med. 308:1009-1012.

12. Einstein, L. P., P. J. Hansen, M. Ballow, A. E. Davis, J. S. David, C. E. Alper, F. S. Rosen, and H. R. Colten. 1977. Biosynthesis of the third component of complement (C3) in vitro by monocytes from both normal and homozygous C3-deficient humans. J. Clin. Invest. 60:963-969.

13. Ruddy, S., and H. R. Colten. 1974. Rheumatoid arthritis biosynthesis of complement proteins by synovial tissues. N. Engl. J. Med. 290:1284-1288.

14. Burger, R., J. Gordon, G. Stevenson, G. Ramadori, B. Zanker, U. Hadding, and D. Bitter-Suermann. 1986. An inherited deficiency of the third component of complement, C3, in guinea pigs. Eur. J. Immunol. 16:7-11.

15. Bottger, E. C., S. Metzger, D. Bitter-Suermann, and R. Burger. 1986. Impaired humoral immune response in complement $\mathrm{C} 3$ deficient guinea pigs: absence of secondary antibody response. Eur. J. Immunol. 16:1231-1235.
16. Ochs, H. D., R. J. Wedgewood, M. M. Frank, S. R. Heller, and S. W. Hosea. 1983. The role of complement in induction of antibody responses. Clin. Exp. Immunol. 53:208-216.

17. Bottger, E. C., T. Hoffmann, U. Hadding, and D. Bitter-Suermann. 1985. Influence of genetically inherited complement deficiencies on humoral immune response in guinea pigs. J. Immunol. 135:4100-4107.

18. Auerbach, H. S., R. D. Baker, W. J. Matthews, Jr., and H. R. Colten. 1984. Molecular mechanism for feedback regulation of C4 biosynthesis in guinea pig peritoneal macrophage. J. Exp. Med. 159:1750-1761.

19. Frank, M. M., J. May, T. Gaither, and L. Ellman. 1971. In vitro studies of complement function in sera of C4-deficient guinea pigs. $J$. Exp. Med. 134:176-187.

20. Roos, M. H., E. Mollenhauer, P. Demant, and C. Rittner. 1982. A molecular basis for the two locus model of human complement component C4. Nature (Lond.). 298:854-856.

21. Chirgwin, J. M., A. E. Przybyla, R. J. McDonald, and W. J. Rutter. 1979. Isolation of biologically active ribonucleic acid from sources enriched in ribonuclease. Biochemistry. 18:5294-5299.

22. Aviv, H., and P. Leder. 1972. Purification of biologically active globin messenger RNA by chromatography on oligothymidylic acid cellulose. Proc. Natl. Acad. Sci. USA. 69:1408-1412.

23. Okayama, H., and P. Berg. 1982. High efficiency cloning of full length cDNA. Mol. Cell. Biol. 2:161-170.

24. Gubler, U., and B. J. Hoffman. 1983. A simple and very efficient method for generating cDNA libraries. Gene. 25:263-269.

25. Messing, J., R. Crea, and P. H. Seeburg. 1981. A system for shotgun DNA sequencing. Nucleic Acids Res. 9:309-321.

26. Janatova, J., J. W. Prahl, and B. F. Tack. 1979. On the presence and the availability of a single sulfhydryl group in both the third (C3) and fourth (C4) components of human complement. In Proceedings of the XIth International Congress of Biochemistry. Abstracts: 524 (No. 08-1-R81). Toronto, Canada.

27. Southern, E. M. 1975. Detection of specific sequences among DNA fragments separated by gel electrophoresis. J. Mol. Biol. 98:503-517.

28. Khan, S. A., and B. W. Erickson. 1982. An equilibrium model of the metastable binding sites of $\alpha_{2}$ macroglobulin and complement proteins C3 and C4. J. Biol. Chem. 257:11864-11867.

29. Iijima, M., T. Tobe, T. Sakamoto, and M. Tomita. 1984. Biosynthesis of the internal thiolester bond of the third component of complement. J. Biochem. 96:1539-1546. 